\title{
Nanohydroxyapatite-Blasted Bioactive Surface Drives Shear-Stressed Endothelial Cell Growth and Angiogenesis
}

\author{
T. S. Pinto, B. R. Martins, M. R. Ferreira, F. Bezerra, and W. F. Zambuzzi (iD \\ Lab. of Bioassays and Cellular Dynamics, Department of Chemical and Biological Sciences, Institute of Biosciences, UNESP- \\ São Paulo State University, 18618-970, Botucatu, São Paulo, Brazil
}

Correspondence should be addressed to W. F. Zambuzzi; w.zambuzzi@unesp.br

Received 17 October 2021; Revised 23 December 2021; Accepted 19 January 2022; Published 23 February 2022

Academic Editor: Frederic Cailotto

Copyright (C) 2022 T. S. Pinto et al. This is an open access article distributed under the Creative Commons Attribution License, which permits unrestricted use, distribution, and reproduction in any medium, provided the original work is properly cited.

\begin{abstract}
Nanosized crystalline hydroxyapatite coating (HAnano ${ }^{\circledR}$ ) accelerates the osteointegration of dental implants which is hypothesized to drive angiogenesis. In order to test this hypothesis, we have subjected shear-stressed human umbilical vein endothelial cells (HUVECs) to a HAnano ${ }^{\circledR}$-enriched medium, as well as to surface presenting dual acid etching (DAE) as a control. To note, the titanium implants were coated with $10 \mathrm{~nm}$ in diameter HA particles using the Promimic HAnano method. Our data reveals that HAnano ${ }^{\circledR}$ modulates higher expression of genes related with endothelial cell performance and viability, such as VEGF, eNOS, and AKT, and further angiogenesis in vitro by promoting endothelial cell migration. Additionally, the data shows a significant extracellular matrix (ECM) remodeling, and this finding seems developing a dual role in promoting the expression of VEGF and control endothelial cell growth during angiogenesis. Altogether, these data prompted us to further validate this phenomenon by exploring genes related with the control of cell cycle and in fact our data shows that HAnano ${ }^{\circledR}$ promotes higher expression of CDK4 gene, while p21 and p15 genes (suppressor genes) were significantly lower. In conjunction, our data shows for the first time that HAnano ${ }^{\circledR}$-coated surfaces drive angiogenesis by stimulating a proliferative and migration phenotype of endothelial cells, and this finding opens novel comprehension about osseointegration mechanism considering nanosized hydroxyapatite coating dental implants.
\end{abstract}

\section{Introduction}

Advances in metallic based biomaterials were dynamically achieved over the last years and have proposed optimized materials in the biomedical field to replace or sustain a lost bone function [1]. There are many characteristics of metal implants that develop essential functions in the success of biomaterial biocompatibility and performance, and these issues affect several biological processes, such as endothelial cells (EC) and blood platelets, responsible for triggering signaling involved with local inflammation, blood coagulation, angiogenesis, and others [2]. Considering the osseointegration biology of dental implants, this is expected that the biology of the reactional tissue surround the implanted devices need to recapitulate principles of osteogenesis in an appositional bone growth manner by requiring a plethora performance of undifferentiated and osteogenic cells and also require specific intracellular pathways to drive the cell adhesion, proliferation, and differentiation $[3,4]$.

Although titanium alloys have been widely used in dentistry mainly considering their characteristics such as stability, mechanical strength, and corrosion resistance [5], there is constant interest in ameliorating their performance by proposing the most sophisticated surfaces considering more than physicochemical properties, applying the knowledge on the bioactive performance of coatings, as well as nanotechnology and how much these surfaces could be predicted considering the biological responses [6, 7]. As it has been related in other studies, a novel surface blasted with nanosized hydroxyapatite $\left(0.02 \mu \mathrm{m}\right.$ thin; HAnano ${ }^{\circledR}$, Promimic, Gothenburg, Sweden) is proposed with already known biological responses $[6,7]$ mainly based on their superhydrophilic surface without changing the microstructure of the dental implants [8]. It is important to mention that $\mathrm{HA}$ is the major 
inorganic component of the bone, and it seems to favor the success of bone cell interaction and osteogenesis [9], and it seems HAnano ${ }^{\circledR}$ be a bioinspired surface.

Recently, we have focused on evaluating the relevance of intracellular signaling pathways in driving the interface of tissue with the implants [10-14], mainly considering the releasing debris/molecules from these materials and whether these materials could affect blood vessels and osteogenesis [15]. Additionally, this is known that the clinical success of the treatment using biomaterials depends on adequate blood apport to deliver important nutrients and biomolecules to the injured tissue during osseointegration and angiogenesis and seems develop a pivotal role maybe coupling osteoblast's differentiation and also enhancing bone healing [16].

Angiogenesis in bone tissue is crucial during development and healing and during its remodeling; it involves a critical interaction with bone cells preceding the onset of osteogenesis by activating a plethora of proangiogenic factors such as vascular endothelial growth factor (VEGF), platelet-derived growth factor (PDGF), transforming growth factor beta (TGF- $\beta$ ), fibroblast growth factors (FGF), and bone morphogenetic proteins (BMPs). In this way, Kusumbe et al. identified a new capillary subtype able to couple angiogenesis to osteogenesis by generating a distinct microenvironment and maintaining perivascular osteoprogenitors [17]. Importantly, these mechanisms seem to require a dynamic extracellular matrix (ECM) remodeling in response to biomaterials and this mechanism is devoted to the matrix metalloproteinase (MMP) activities [18].

Blood vessels play a pivotal role in bone development, remodeling, and homeostasis; its being in the angiogenesis is crucial during the bone healing surrounding the dental implants. In this way, although some progress has been achieved regarding the HAnano ${ }^{\circledR}$ promoting osteogenesis, very few is documented about angiogenesis in this aspect. Thus, we have hypothesized that HAnano ${ }^{\circledR}$ drives angiogenesis surrounding the implants and guarantees the success of its osseointegration when coating titanium-based dental implants. To better address this issue, we have subjected shear-stressed human umbilical vein endothelial cells (HUVECs) to HAnano ${ }^{\circledR}$-enriched medium up to 24 hours when the biological samples were collected to allow further the molecular analysis. Importantly, the endothelial cells were maintained in vitro considering the shear stress mimicking blood tensional forces [19, 20]. Summarizing, our data shows clearly that HAnano ${ }^{\circledR}$ activates genes related with angiogenesis and promotes the proliferation/migration of endothelial cells by coordinating ECM remodeling and higher expression of genes related with endothelial cell growth and migration.

\section{Material and Methods}

\subsection{Implants and Reagents}

2.1.1. Implants. The titanium-based dental implants evaluated in this study presenting DAE surfaces and EPIKUT ${ }^{\circledR}$ with HAnano ${ }^{\circledR}$ surface were obtained from S.I.N. Implant System, Sao Paulo, Brazil, with $3.5 \mathrm{~mm}$ in diameter and
$10.0 \mathrm{~mm}$ in length. HAnano ${ }^{\circledR}$ surface was obtained using the Promimic HAnano method [21, 22]. Briefly, the samples were dipped into a stable particle suspension containing $10 \mathrm{~nm}$ in diameter HA particles followed by a heat treatment at $550^{\circ} \mathrm{C}$ for $5 \mathrm{~min}$ in a nitrogen atmosphere. Importantly, the calcium to phosphor ratio is 1.67 . The surfactantmediated process allows better control of the chemical composition of the coating [22], which has a thickness of less than or equal to $150 \mathrm{~nm}$.

2.1.2. Reagents. RPMI medium, fetal bovine serum (FBS), trypsin, penicillin, and streptomycin (antibiotics) were purchased from Nutricell (Campinas, Sao Paulo, Brazil). Trypan Blue (T6146), acetic acid glacial (695092), (3-(4,5-dimethylthiazol-2-yl)-2,5-diphenyltetrazolium bromide) (MTT) (M2128), ethanol (459844), and crystal violet dye (C0775) were purchased from Sigma Chemical Co. (St. Louis, MO, USA). TRIzol ${ }^{\mathrm{TM}}$ reagent (15596026), DNase I (18068015), and High-Capacity cDNA Reverse Transcription Kit (4368814) were obtained from Thermo Fisher Scientific Inc. (Waltham, Massachusetts, EUA). GoTaq qPCR Master Mix (A6002) was purchased from PROMEGA (Madison, Wisconsin, EUA). Oligonucleotides for gene expression, microRNA, and promoter methylation were purchased from Exxtend (Campinas, São Paulo, Brazil).

2.2. Cell Culture. In this study, the cell line used was human umbilical vein endothelial cells (HUVECs) (ATCC; CRL1730; passage $<10)$. HUVECs were cultivated in RPMI medium (Nutricell, Campinas, Brazil) supplemented with penicillin $(100 \mathrm{U} / \mathrm{mL})$ and streptomycin $(100 \mathrm{mg} / \mathrm{mL})$ and $10 \%$ fetal bovine serum (FBS) and maintained at $37^{\circ} \mathrm{C}$ with $5 \% \mathrm{CO}_{2}$. HUVECs were seeded in the peripheral area of the modified $100 \mathrm{~mm}$ culture dishes to allow the application of shear stress methodology. To note, the modified $100 \mathrm{~mm}$ culture dishes were obtained by bonding at the bottom a $60 \mathrm{~mm}$ culture dishes into their center using medical silicone, and thereafter, the dishes were sterilized using UV light for $30 \mathrm{~min}$ [20, 23-25] (Figure 1).

2.3. Shear Stress Model. HUVECs were previously seeded onto the peripheral area of the modified culture dishes (as described earlier) and then subjected to the orbital shear stress-induced tension force, using an orbital shaker (Scilogex, Rocky Hill, CT) positioned inside of the cell culture incubator, at $37^{\circ} \mathrm{C}$ in the presence of $\mathrm{CO}_{2}$ and $95 \%$ humidity, as proposed by others [19, 20, 23, 26-28]. The shear stress model performed here uses an orbital shaker respecting the formula of the maximal wall shear stress: $\tau \max =\alpha \sqrt{ } \rho \eta(2$ $\pi f) 3$, in which $\tau$ max (Pascal unit) is the shear stress, $\alpha$ is the radius of orbital rotation $(12 \mathrm{~cm}), \rho$ is the density of the cell culture medium $\left(937.5 \mathrm{~kg} / \mathrm{m}^{3}\right), \eta$ is the viscosity of the cell culture medium $\left(7.5 \times 10^{-4} \mathrm{Pas}\right)$, and $f$ is the frequency of rotation. The titanium-enriched medium was used to treat monolayers of endothelial cells in this shear stress workflow in a rotation frequency of $100 \mathrm{rpm}$, respecting the protocol of previous studies, which is within the range of physiological arterial shear stress $(\sim 1-4 \mathrm{~Pa})$. Thus, HUVECs remained in this workflow up to $24 \mathrm{~h}$, being 


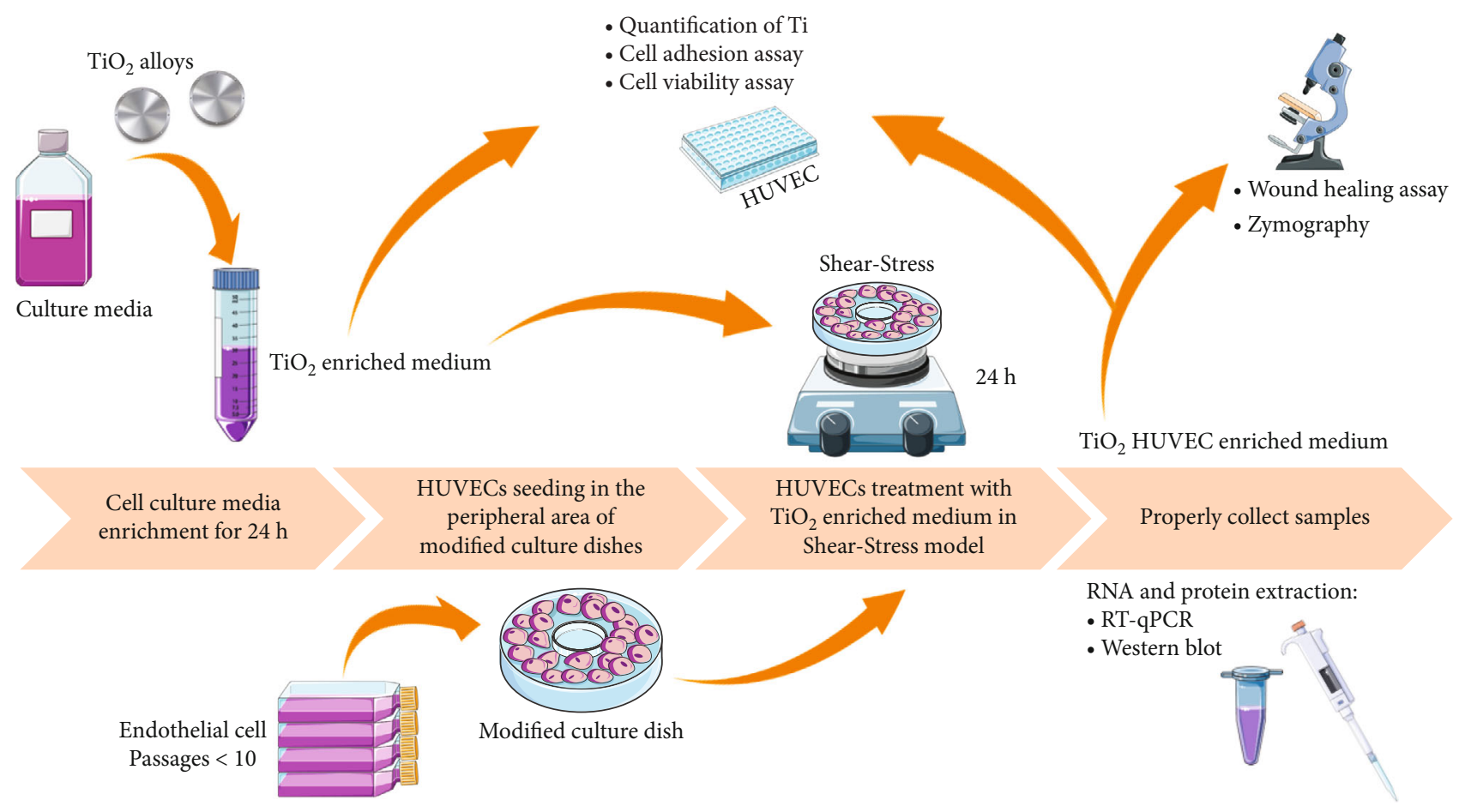

FIgURE 1: Experimental design of this study. In order to evaluate the endothelial cell (EC) behavior in response to HAnano ${ }^{\circledR}$, the conditioned medium was obtained in according to ISO 10993:2016 and further used to treat the endothelial cells for $24 \mathrm{~h}$ in an in vitro mimicking shear stress model, when the samples were properly collected to allow the molecular analysis.

subjected to different treatments: HAnano $^{\circledR}$-enriched medium and dual acid-etched- (W/DAE-) enriched medium; both were compared to the control (when the cultures were maintained without any treatment). The samples of each group were properly collected to allow the molecular analysis, as schematized in Figure 1.

2.4. Conditioned Medium Obtention. To prepare the titaniumenriched medium, both dual acid-etching (DAE) treating surface (named W/DAE) and the nanohydroxyapatite-blasted surfaces (named HAnano ${ }^{\circledR}$ ) were incubated in cell culture media (RPMI) without $\mathrm{FBS}$ up to $24 \mathrm{~h}$ at $37^{\circ} \mathrm{C}, 5 \% \mathrm{CO}_{2}$, and 95\% humidity $(0.2 \mathrm{~g} / \mathrm{mL}(w / v)$; ISO 10993:2016), as we have proposed earlier to evaluate biomaterials $[11,29,30]$. This is expected that the conditioned medium contains molecules released from those metallic alloys and might affect the biology of endothelial cells. The cytotoxic effect of those implants was measured using MTT assay.

2.5. Ti Amount Was Measured by Graphite Furnace Atomic Absorption Spectrometry. The conditioned medium was used to measure Ti element content before and after treating the HUVECs in the shear stress model. Importantly, Ti determination was performed by a graphite furnace atomic absorption spectrometry, in which the graphite tube's heating program optimized for Ti determinations was based on the procedure described by Silva et al. [31].

2.6. Cell Viability Assay. The conditioned medium was prepared using the ISO 10993:2016, as well as it has been used by Zambuzzi et al. [32]. To prepare the conditioned medium, the implants were incubated in RPMI up to 24 hours. Previously, the cells were seeded on 96-well plates $\left(5 \times 10^{4}\right.$ cells $\left./ \mathrm{mL}\right)$ and incubated up to $24 \mathrm{~h}$ with the conditioned medium, when the culture media was substituted by $180 \mu \mathrm{L} /$ well of each sample extract plus $20 \mu \mathrm{L}$ FBS (resulting a final concentration of $10 \%$ of FBS). The control cultures were considered maintaining cells under classical cell culture conditions. The experimental time was 24 hours, when the cell viability was assessed by adding $1 \mathrm{mg} / \mathrm{mL}$ of $3-(4,5-$ dimethyl-2-thiazolyl)-2,5-diphenyl-2H-tetrazolium bromide (MTT) to measure the mitochondrial dehydrogenase activity by MTT reduction up to 3 hours into $\mathrm{CO}_{2}$ incubator, where there is a conversion of the yellow water-soluble tetrazolium salt MTT into the purple-colored soluble compound of formazan. The formazan was solubilized into ethanol, and the absorbance measured at $570 \mathrm{~nm}$ (Synergy II; BioTek Instruments, USA).

2.7. Cell Adhesion Assay. For evaluating cell adhesion performance, endothelial cells were trypsinized, properly counted, and then reseeded $\left(1 \times 10^{4}\right.$ cells per well $)$ in sextuplicate into 96-well plates in implant-conditioned medium supplemented with $10 \%$ of FBS and $1 \%$ antibiotics up to $24 \mathrm{~h}$. Then, the nonadherent cells were removed by washing with PBS $\left(37^{\circ} \mathrm{C}\right)$ and the adherent cells fixed in glacial acetic acid and absolute ethanol solution $(3: 1 ; v / v)$ for 10 minutes at room temperature (RT). Thereafter, the cells were stained with $0.1 \%(w / v)$ crystal violet for 10 minutes at RT. The excess dye was retained by decanting and washing $(2 \mathrm{x})$ with 
TABLE 1: Expression primers sequences and qPCR cycle conditions.

\begin{tabular}{|c|c|c|c|}
\hline Gene & Primer & $5^{\prime}-3^{\prime}$ sequence & Work condition \\
\hline \multirow{3}{*}{ AKT } & Forward 1 & CAGCGCGGCCCGAAGGAC & \multirow{3}{*}{$95^{\circ} \mathrm{C}-3 \mathrm{~s}, 55^{\circ} \mathrm{C}-8 \mathrm{~s}, 72^{\circ} \mathrm{C}-20 \mathrm{~s}$} \\
\hline & Forward 2 & GGACTCCCGTTTGCGCCAGT & \\
\hline & Reverse & GACGCTCACGCGCTCCTCTC & \\
\hline \multirow{2}{*}{ CFL1 } & Forward & TGTGCGGCTCCTACTAAACG & \multirow{2}{*}{$95^{\circ} \mathrm{C}-3 \mathrm{~s}, 55^{\circ} \mathrm{C}-8 \mathrm{~s}, 72^{\circ} \mathrm{C}-20 \mathrm{~s}$} \\
\hline & Reverse & TCCTTGACCTCCTCGTAGCA & \\
\hline \multirow{2}{*}{ P15 } & Forward & GGGACTAGTGGAGAAGGTGC & \multirow{2}{*}{$95^{\circ} \mathrm{C}-3 \mathrm{~s}, 55^{\circ} \mathrm{C}-8 \mathrm{~s}, 72^{\circ} \mathrm{C}-20 \mathrm{~s}$} \\
\hline & Reverse & CATCATCATGACCTGGATCGC & \\
\hline \multirow{2}{*}{ P21 } & Forward & GCTGCCGAAGTCAGTTCCTT & \multirow{2}{*}{$95^{\circ} \mathrm{C}-3 \mathrm{~s}, 55^{\circ} \mathrm{C}-8 \mathrm{~s}, 72^{\circ} \mathrm{C}-20 \mathrm{~s}$} \\
\hline & Reverse & ATCTGTCATGCTGGTCTGCC & \\
\hline \multirow{2}{*}{ CDK2 } & Forward & CTTTGCTGAGATGGTGACTCG & \multirow{2}{*}{$95^{\circ} \mathrm{C}-3 \mathrm{~s}, 55^{\circ} \mathrm{C}-8 \mathrm{~s}, 72^{\circ} \mathrm{C}-20 \mathrm{~s}$} \\
\hline & Reverse & GCCTCCCAGATTCCTCATGC & \\
\hline \multirow{2}{*}{ CDK4 } & Forward & СТCTCTAGCTTGCGGCCTG & \multirow{2}{*}{$95^{\circ} \mathrm{C}-3 \mathrm{~s}, 55^{\circ} \mathrm{C}-8 \mathrm{~s}, 72^{\circ} \mathrm{C}-20 \mathrm{~s}$} \\
\hline & Reverse & GCAGGGATACATCTCGAGGC & \\
\hline \multirow{2}{*}{ VEGF } & Forward & TGCAGATTATGCGGATCAAACC & \multirow{2}{*}{$95^{\circ} \mathrm{C}-3 \mathrm{~s}, 55^{\circ} \mathrm{C}-8 \mathrm{~s}, 72^{\circ} \mathrm{C}-20 \mathrm{~s}$} \\
\hline & Reverse & TGCATTCACATTTGTTGTGCTGTAG & \\
\hline \multirow{2}{*}{ ENOS } & Forward & TATTTGATGCTCGGGACTGC & \multirow{2}{*}{$95^{\circ} \mathrm{C}-3 \mathrm{~s}, 55^{\circ} \mathrm{C}-8 \mathrm{~s}, 72^{\circ} \mathrm{C}-20 \mathrm{~s}$} \\
\hline & Reverse & AAGATTGCCTCGGTTTGTTG & \\
\hline \multirow{2}{*}{ P38 } & Forward & GAGAACTGCGGTTACTTA & \multirow{2}{*}{$95^{\circ} \mathrm{C}-3 \mathrm{~s}, 55^{\circ} \mathrm{C}-8 \mathrm{~s}, 72^{\circ} \mathrm{C}-20 \mathrm{~s}$} \\
\hline & Reverse & ATGGGTCACCAGATACACAT & \\
\hline \multirow{3}{*}{ ERK } & Forward 1 & AACAGGCTCTGGCCCACCCAT & \multirow{3}{*}{$95^{\circ} \mathrm{C}-3 \mathrm{~s}, 55^{\circ} \mathrm{C}-8 \mathrm{~s}, 72^{\circ} \mathrm{C}-20 \mathrm{~s}$} \\
\hline & Forward 2 & CGCCCCTCCAAACGGCTCAA & \\
\hline & Reverse & GCAGCGCCTCCCTTGCTAGA & \\
\hline \multirow{2}{*}{ ITGB1 } & Forward & GCCGCGCGGAAAAGATGAA & \multirow{2}{*}{$95^{\circ} \mathrm{C}-3 \mathrm{~s}, 55^{\circ} \mathrm{C}-8 \mathrm{~s}, 72^{\circ} \mathrm{C}-20 \mathrm{~s}$} \\
\hline & Reverse & TGCTGTTCCTTTGCTACGGT & \\
\hline \multirow{2}{*}{ FAK } & Forward & TCAGCTCAGCACAATCCTGG & \multirow{2}{*}{$95^{\circ} \mathrm{C}-3 \mathrm{~s}, 55^{\circ} \mathrm{C}-8 \mathrm{~s}, 72^{\circ} \mathrm{C}-20 \mathrm{~s}$} \\
\hline & Reverse & CTGAAGCTTGACACCCTCGT & \\
\hline \multirow{2}{*}{ SRC } & Forward & CAACACAGAGGGAGACTGGT & \multirow{2}{*}{$95^{\circ} \mathrm{C}-3 \mathrm{~s}, 55^{\circ} \mathrm{C}-8 \mathrm{~s}, 72^{\circ} \mathrm{C}-20 \mathrm{~s}$} \\
\hline & Reverse & AGCTTCTTCATGACCTGGGC & \\
\hline \multirow{2}{*}{$18 \mathrm{~S}$} & Forward & CGGACAGGATTGACAGATTGATAGC & \multirow{2}{*}{$95^{\circ} \mathrm{C}-3 \mathrm{~s}, 55^{\circ} \mathrm{C}-8 \mathrm{~s}, 72^{\circ} \mathrm{C}-20 \mathrm{~s}$} \\
\hline & Reverse & TGCCAGAGTCTCGTTCGTTATCG & \\
\hline
\end{tabular}

distilled water. Finally, the dye was extracted with $10 \%$ acetic acid $(v / v)$ and the optical density measured at $550 \mathrm{~nm}$ using a microplate reader (Biotek Co., Winooski, VT). For the positive control, the cells were seeded on polystyrene surface (control group (Ctrl)). The results were expressed as percent of the control (100\%).

2.8. Angiogenesis Assay. The cell migration and angiogenesis were estimated by using a scratch assay, as performed earlier [19]. The scratch assay estimates the cell migration and angiogenesis. Briefly, the cells were cultured in 12-well plates at $4 \times 10^{4} \mathrm{cells} / \mathrm{cm}^{2}$, and after $100 \%$ confluence, an introduced area was cleared using a pipet tip [19] and then a monitoring of the angiogenesis and the migration of the ECs up to $12 \mathrm{~h}$ and $16 \mathrm{~h}$. Thereafter, the cultures were subjected to fixation with $4 \%$ PFA and stained with Alizarin Red S. In the analysis of the angiogenesis in vitro, the wound healing area was measured in an inverted microscope with a coupled digital camera (Zeiss) and the acquired images analyzed using the Image software (NIH, Bethesda, MD).
2.9. Total mRNA Isolation and RT-qPCR Analysis. In order to evaluate the molecular behavior of genes related with angiogenesis and cellular survival in response to HAnano ${ }^{\circledR}$, the cells were newly subjected to the conditioned medium containing the released molecules and further harvested and total mRNA properly isolated using Ambion TRIzol Reagent (Life Sciences, Thermo Fisher Scientific Inc., Waltham, MA) and treated with DNase I (Invitrogen, Carlsbad, CA). Complementary DNA (cDNA) synthesis was performed with the High-Capacity cDNA Reverse Transcription Kit (Applied Biosystems, Foster City, CA) according to the manufacturer's instructions. Real-Time Reverse Transcriptase qPCR was carried out in a total of $10 \mu \mathrm{L}$, containing PowerUp ${ }^{\mathrm{TM}}$ SYBR $^{\mathrm{TM}}$ Green Master Mix $2 \times(5 \mu \mathrm{L}$; Applied Biosystems, Foster City, CA), $0.4 \mu \mathrm{M}$ of each primer, $50 \mathrm{ng}$ of cDNA, and nuclease-free $\mathrm{H}_{2} \mathrm{O}$. Results were expressed as relative amounts of the transcripts using $18 \mathrm{~s}$ as reference gene (housekeeping gene), using the cycle threshold $(\mathrm{Ct})$ method. Primers and work conditions are described in Table 1. 


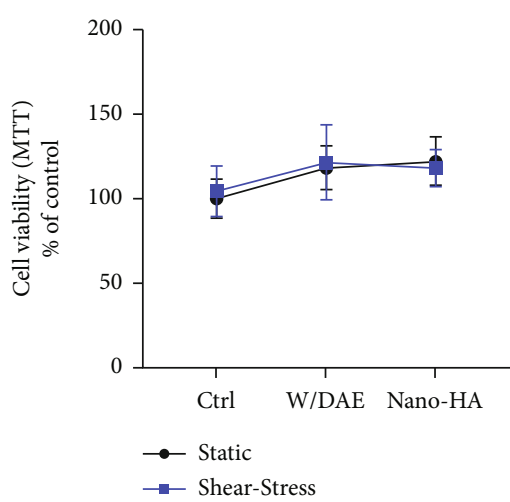

(a)

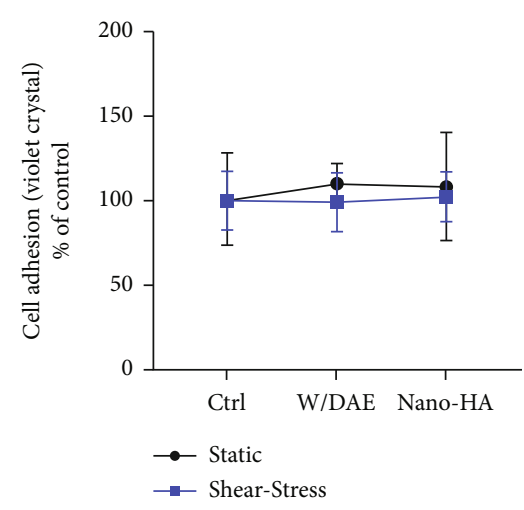

(b)

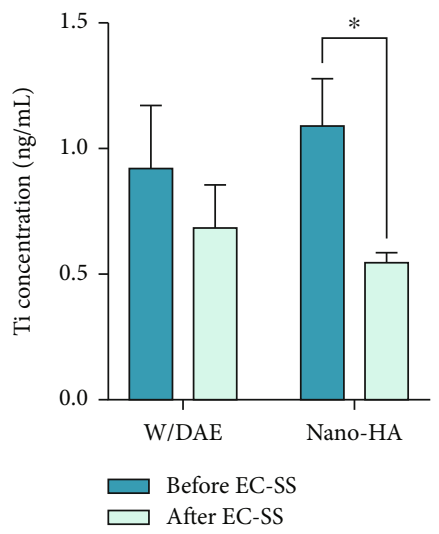

(c)

Figure 2: HAnano ${ }^{\circledR}$ cytotoxicity and the capacity of shear-stressed endothelial cell in capturing medium-soluble titanium. The titaniumenriched medium was obtained in according to ISO 10993:2016 by incubating the implants containing DAE (w/DAE) or nanosized hydroxyapatite $\left(\mathrm{HAnano}^{\circledR}\right.$ ) coatings up to 24 hours and thereafter used to subject endothelial cell. Our data shows there is no effect on endothelial cell viability (a) and endothelial cell adhesion (b). Additionally, it was confirmed that shear-stressed endothelial cell captures a significant amount of medium-soluble titanium mainly responding to HAnano ${ }^{\circledR}$. A significant difference was considered when $p<0.05$.

2.10. Statistical Analyses. Results were represented as mean \pm standard deviation (SD). The samples assumed a normal distribution, and they were subjected to Student's $t$-test (two-tailed) with $p<0.05$ considered statistically significant. In the experiment where there were more than two groups, we used one-way ANOVA with Tukey's multiple comparisons test, in order to compare all pairs of groups. In this case, the significance level was considered when alpha $=0.05$ (95\% confidence interval). The software used was GraphPad Prism 7 (GraphPad Software, USA).

\section{Results}

Firstly, we have focused on evaluating whether the different surfaces of titanium proposed in this study were able to develop some cytotoxicity in endothelial cells. Thus, Figure 2(a) shows that there is no significance effect on mitochondrial activities in response to both surfaces, as well as the cell adhesion, once Figure 2(b) brings the same behavior of endothelial cells responding to the materials, without any changes on the outcomes obtained by shear-stressed endothelial cells. Additionally, we have also investigated whether endothelial cells were able to capture titanium released from the materials, and our data shows for the first time there is a significant uptake of titanium by shear-stressed endothelial cells responding to HAnano ${ }^{\circledR}$ super hydrophilic surface (Figure 2(c)) and this data could explain some metabolic changes in those cells.

Thereafter, in order to investigate whether the Tienriched medium was able to change the metabolism of shear-stressed endothelial cells, we evaluated genes related with endothelial cells phenotype: importantly, our data shows that shear-stressed endothelial cells responding to $\mathrm{HAnano}^{\circledR}$ super hydrophilic surface presents a significant higher expression profile of VEGF (Figure 3(a); about 10fold changes), eNOS (Figure 3(b); about 4-fold changes), and AKT (Figure 3(c); about 2.5-fold changes).

In addition, this data prompted us to better evaluate the behavior of shear-stressed endothelial cells by considering a well-accepted in vitro methodology. In general, shearstressed endothelial cells responding to Ti-enriched medium presented a better performance in cell migration and angiogenesis in vitro than control cultures (Figures 4(a)-4(j)), with better outcomes obtained in response to HAnano ${ }^{\circledR}$ superhydrophilic surface in 16 hours (Figure 4). Figure 4(k) brings the analysis of the wounding area; considered here, the capacity of endothelial cells migrate responding to the specific treatments. 


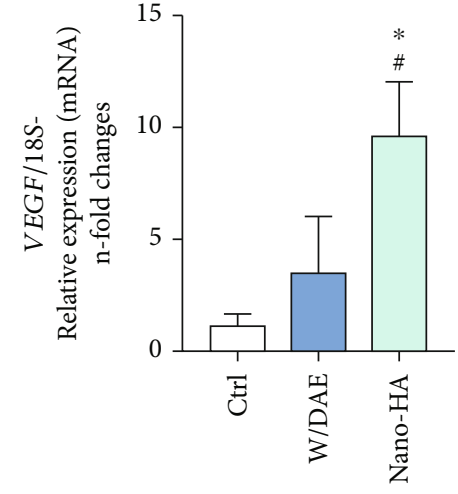

(a)

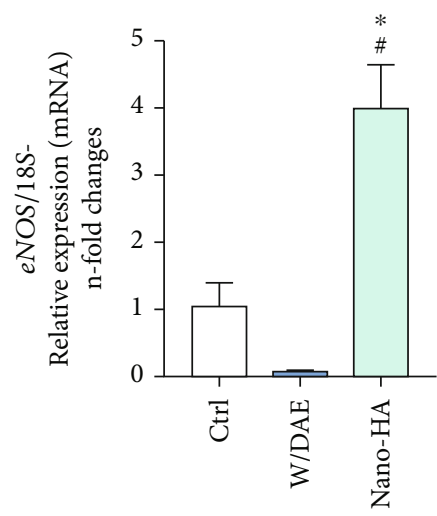

(b)

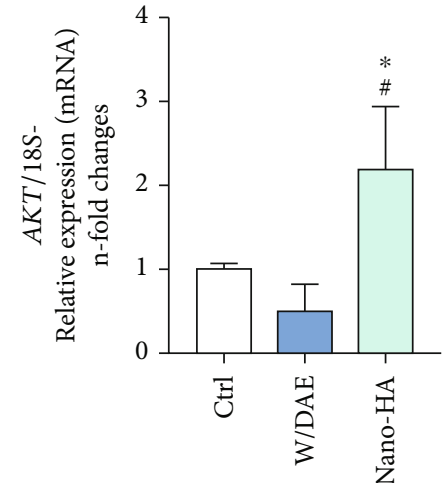

(c)

FIgURE 3: HAnano ${ }^{\circledR}$ upmodulates EC phenotype-related genes. Shear-stressed endothelial cell were subjected to Ti-enriched medium for 24 hours, and the samples were harvested to allow gene expression using RT-qPCR methodology. Our data shows there is a significant higher expression of VEGF (a) and eNOS (b) genes in response to HAnano ${ }^{\circledR}$, as well as AKT gene (c). The graphs bring the $n$-fold change of the profile of transcripts normalized to the $18 \mathrm{~S}$ gene (housekeeping gene). Significant differences were considered when $p<0.05$, represented by * when compared to the Ctrl group and by ${ }^{*}$ when compared to the W/DAE group.

As migration and proliferation actions of the cells requires a dynamic mechanism of extracellular matrix (ECM) remodeling, we also investigated the behavior of matrix metalloproteinase (MMP) activities, and our data supports that shear-stressed endothelial cells responding to the Ti-enriched medium promoted a higher activity of MMP2 (Figures 5(a)-5(d)). Here, we need to consider the limitation of the experimental model used in this study, and the data supports a significant stimulus of Ti-enriched medium on remodeling ECM in endothelial cells.

To better understand the behavior of shear-stressed endothelial cells responding to Ti-enriched medium obtained by surfaces DAE and HAnano ${ }^{\circledR}$, we now investigated the relevance of genes related with cell proliferation. Our data shows there is a significant downregulation of genes of MAPKs p38 and ERK in endothelial cells responding to Ti-enriched medium, and it does not matter the kind of surface evaluated (Figures 6(a) and 6(b)). In addition, specific genes related with cell cycle progression were also investigated and Figure 6(c) shows there is a significant higher expression of CDK4 gene by shear stressed endothelial cells responding to $\mathrm{HAnano}^{\circledR}$ super hydrophilic surface, while CDK2 gene was significant downregulated (Figure 6(d)). These data could explain the findings shown previously here in cell migration and angiogenesis in response to HAnano ${ }^{\circledR}$ surfaces. Importantly, in this context and considering the regulation of cell cycle activity of endothelial cells, we also investigated the behavior of genes related to negatively control cell proliferation, p15 and p21, and our data shows there is a significant downregulation of the expression profile of these both genes in endothelial cells responding to $\mathrm{Ti}$ enriched medium, mainly considering p21 gene in response to HAnano ${ }^{\circledR}$ (Figures 6(e) and 6(f)).

\section{Discussion}

Considering the osseointegration-related microenvironment, angiogenesis is an important biological event to be considered, which plays a pivotal role on supplying cells, nutrients, and gases changes as well as clearing up waste molecules from the cellular metabolism. In addition, the vascularization plays crucial role in bone healing, mainly considering the coupling mechanism between bone cells and endothelial cells by angiocrine signals addressing bone cell activities and further osteogenesis. Once angiogenesis in response to biomaterials is barely understood, we decided to better evaluate the behavior of shear-stressed endothelial cells responding to Ti-enriched medium obtained from 2 different types of modified surfaces, as follows: (1) subjected to DAE (w/DAE) and (2) DAE-modified surfaces coated with nanosized HA (HAnano ${ }^{\circledR}$ ). It is important to mention that we have previously shown that HAnano ${ }^{\circledR}$ superhydrophilic surface drives osteoblast performance when modifying dental implants surfaces [33].

In this study, our data shows that dental implants having HAnano ${ }^{\circledR}$ superhydrophilic surfaces generates an adequate microenvironment to drive angiogenesis and this study could explain the success of its clinical application [34]. Firstly, our data shows that shear-stressed endothelial cells significantly uptake titanium released from $\mathrm{HAnano}^{{ }_{-}}$ enriched medium and this data opened a set of question about the behavior of endothelial cells and angiogenesis and, in part, is shown here. Importantly, our data shows that conditioned medium by HAnano ${ }^{\circledR}$ promotes higher expression of important genes related with endothelial cell phenotype: VEGF and eNOS. Importantly, these data bring important evidences to suggest the relevance of angiogenesis during tissue remodeling microenvironment surrounding the dental implants. This is known that angiogenesis is regulated by many growth factors and molecules, and in this scenario, VEGF and nitric oxide (NO) are potent angiogenic factors.

Mechanistically, the capacity of VEGF in promoting bone regeneration and healing has been shown in several biological models [35-37]. VEGF is a very important growth factor in the vascular system driving endothelial cell growth 


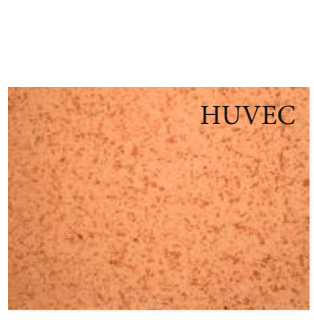

(a)

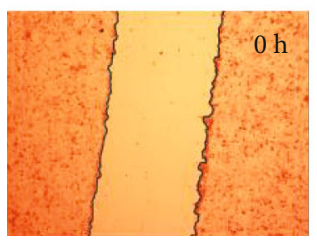

(b)

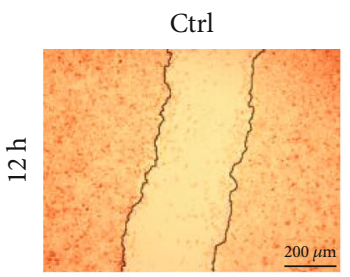

(c)

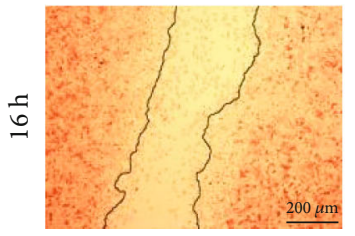

(g)

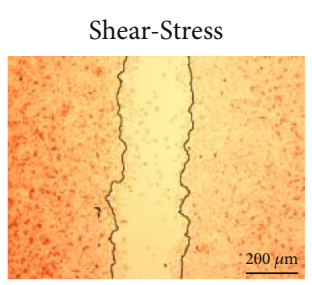

(d)

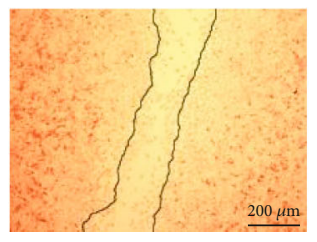

(h)

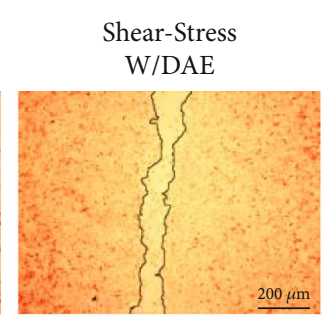

(e)

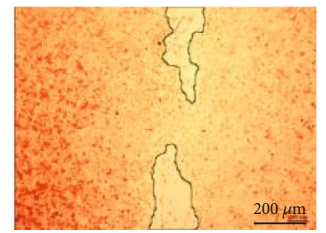

(i)

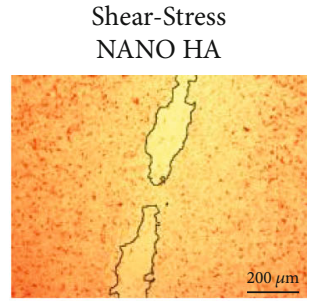

(f)

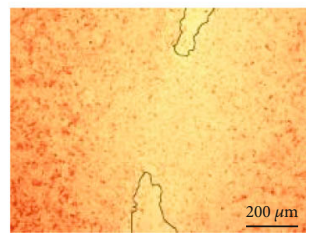

(j)

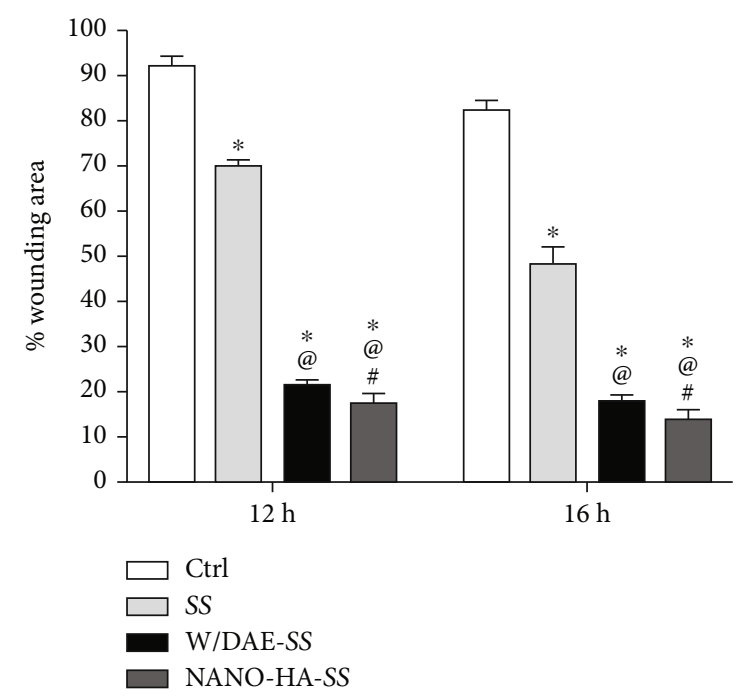

(k)

Figure 4: The angiogenic effect of HAnano ${ }^{\circledR}$ was measured by a wound healing assay. (a) Endothelial cell forming a confluent monolayer. (b) In vitro "wound" was created by a straight-line scratch across the endothelial cell monolayer (T0). At time 0 (T0), the endothelial cell were scratched and subjected to conditioned medium, respecting the culture groups, as follows: Ctrl: RPMI (c, g); shear stress: endothelial cell in shear stress model $(\mathrm{d}, \mathrm{h})$; shear stress W/DAE: shear-stressed endothelial cell subjected with Ti-enriched medium by DAE (w/DAE) $(e, i)$; shear stress HAnano ${ }^{\circledR}$ : shear-stressed endothelial cell subjected with Ti-enriched medium by HAnano ${ }^{\circledR}$ (nano-HA) (f, j). The scratch wound assay was used to assess the migration capacity of the endothelial cells under different conditioned media. The wound area was estimated by calculating the cell-free area in captured images using the ImageJ software (NIH, Bethesda, MD). The migration rate is expressed in percentage as the change in the wound area over time, the scratch area at time point 0 hours was set to $100 \%$, and the other ones are represented as wound closure expressed as the remaining area uncovered by the cells in percentage. (k) The statistically significant changes are represented by ${ }^{*}$ when compared with the Ctrl group, by ${ }^{@}$ when compared to the SS group, and by ${ }^{*}$ when compared to the W/DAE SS group. Significant differences were considered when $p<0.05$.

and survival, as well as develops a signaling hub with osteogenesis by regulating the expression of bone morphogenetic proteins (BMPs) $[38,39]$, and VEGF may be released during matrix remodeling orchestrated by MMP-mediated matrix breakdown, which induces vascular invasion and angiogenesis [40]. Importantly, we have shown previously that titanium-based devices drive matrix remodeling by upmodulating the activities of matrix metalloproteinases (MMPs) $[6,29,41]$ and this recapitulates events are also shown in bone development and healing [27, 42-47]. Importantly, this could be a prerequisite also to favor the angiogenesis process throughout the distraction osteogenesis phase, but to a lesser extent during the phase of consolidation [48], respecting distinct phases of bone repair progress.

Another concern evaluated here was the possibility of shear-stressed endothelial cells in expressing eNOS in response to nanosized $\mathrm{HA}$, once the role of the messenger molecule nitric oxide has been evaluated in fracture healing 


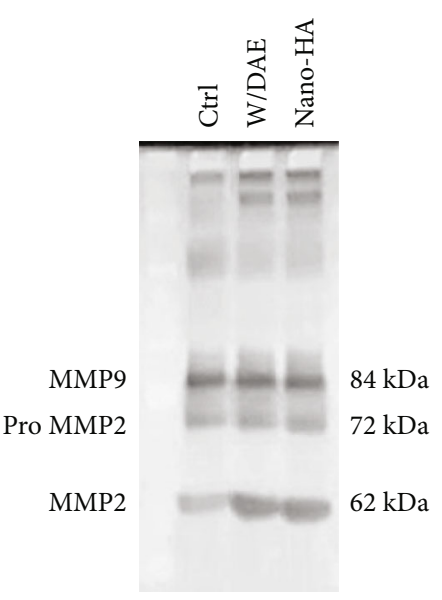

(a)

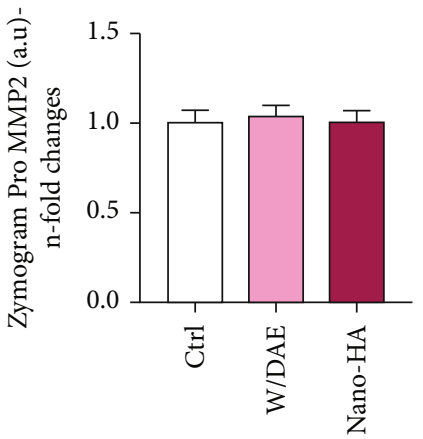

(c)

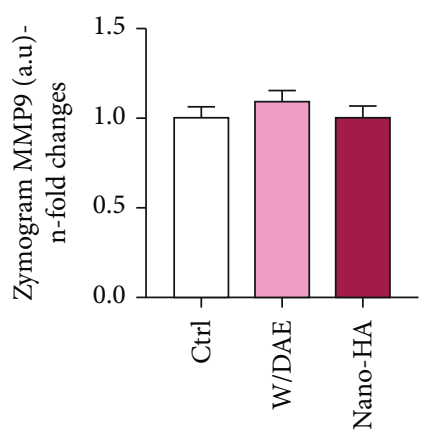

(b)

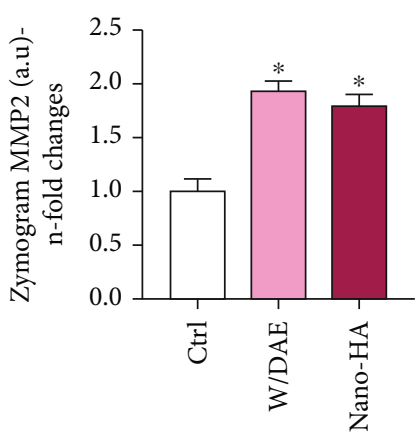

(d)

Figure 5: Both Ti-related surfaces with DAE or HAnano ${ }^{\circledR}$ promote higher activity of MMP2 enzyme. The ECM remodeling was evaluated by checking the activities of MMPs in response to titanium-enriched media indirectly obtained by 2 different surfaces DAE (w/DAE) and nanohydroxyapatite-blasted titanium surface $\left(\mathrm{HAnano}^{\circledR}\right)$ applying zymography technology (a). MMP2 activity showed different activities profiles, mainly observed higher in response to both treatments when compared to Ctrl (b-d). Differences were considered significant when $p<0.05$, represented by * when compared with the Ctrl group. MMP: matrix metalloproteinase.

[49], and NO is synthesized by three kinds of nitric oxide synthase (NOS): inducible NOS (iNOS), endothelial (eNOS), and neuronal (nNOS). Regarding eNOS, our data show a very similar profile of VEGF and seems to develop a pivotal role in endothelial cell activity to maintain endothelial homeostasis during bone healing surrounding the implanted devices. As we have also noticed from the data, a higher expression of AKT gene in endothelial cells responds to HAnano $^{\circledR}$; this seems obvious suggesting that the angiogenic stimulus of HAnano ${ }^{\circledR}$ requires AKT/eNOS axis in shearstressed endothelial cells; once, this is widely related in the literature that AKT activates eNOS via activation of mTOR $[50,51]$. Thus, AKT is closely linked to the formation of new blood vessels through the activation of endothelial nitric oxide synthase (eNOS) [52], which is responsible for relaxing vascular smooth muscle and also mediates angiogenesis by controlling the action of VEGF [52-54]. Moreover, Akt also regulates PI3K-mediated cell survival and is sufficient to block cell death induced by a variety of apoptotic stimuli $[55,56]$ and the importance of PI3K in endothelial cell was shown by using wortmannin as an inhibitor [28].
Finally, we have also investigated whether these molecular mechanisms led to the proliferation and migration of endothelial cells. Thus, we have further investigated angiogenesis in vitro by using a well-accepted functional assay and our data validates this hypothesis; once, endothelial cells subjected to HAnano ${ }^{\circledR}$ presented better cell cycle performance by upmodulating CDK4 gene and ECM remodeling, while both investigated cell cycle suppressor genes p15 and p21 were downmodulated. ECM remodeling seems to be an important hub in endothelial cells responding to HAnano $^{\circledR}$ by favoring as a prerequisite to VEGF expression and also related with the growth of cells during angiogenesis. Generally, this is reasonable to suggest that HAnano ${ }^{\circledR}$ promotes an ideal microenvironment for osseointegration by regulating genes related with endothelial cell growth, such as VEGF, which could play an autrocrine loop and AKT/ eNOS signaling, culminating with EC proliferation and angiogenesis, which could be coupled to osteogenesis; once, we have shown earlier the osteogenic effect of HAnano ${ }^{\circledR}$.

In conjunction, this study brings sufficient in vitro data to support the angiogenic effect of HAnano ${ }^{\circledR}$-coated titanium surface by modulating the proliferative and migration 


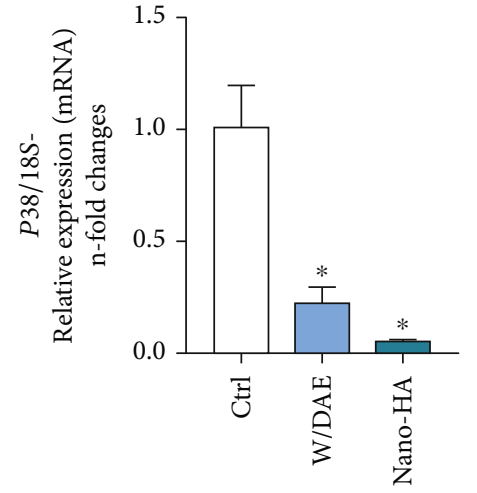

(a)

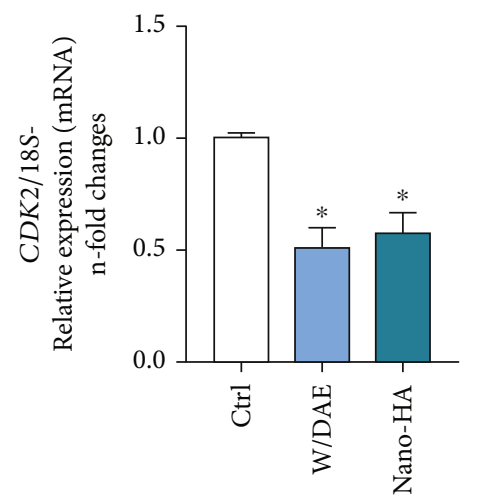

(d)

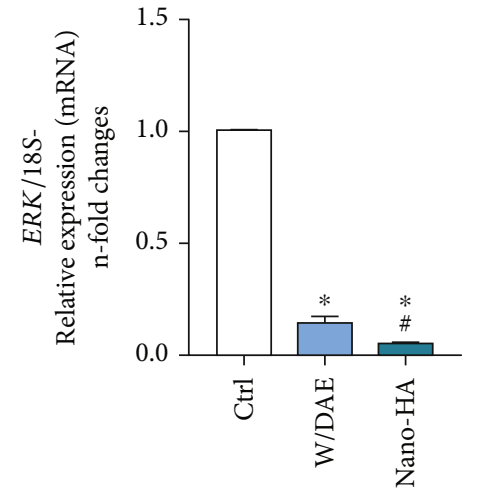

(b)

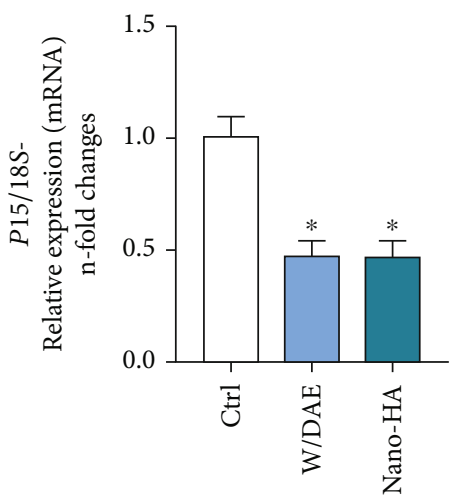

(e)

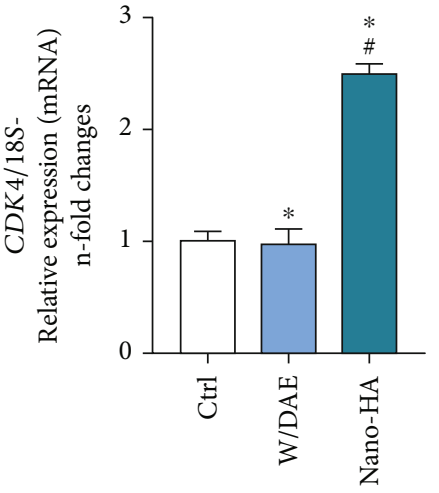

(c)

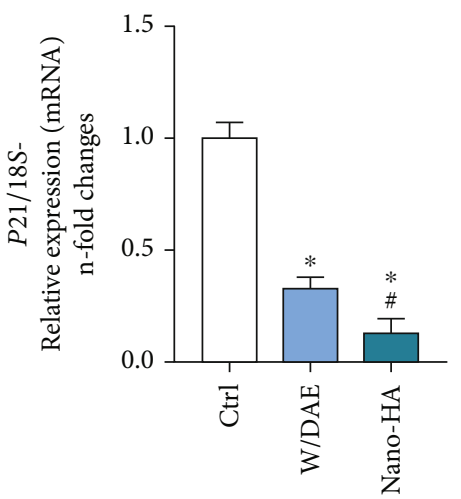

(f)

FIgURE 6: CDK4 is upmodulated in response to HAnano ${ }^{\circledR}$. Thereafter, understanding its relevance on endothelial cells migration and angiogenesis, we postulated the hypothesis that HAnano ${ }^{\circledR}$ modulates cell cycle-related genes. Although MAPKs p38 (a) and ERK (b) genes were downregulated in response to $\mathrm{HAnano}^{\circledR}, \mathrm{CDK} 4$ gene expression was significantly higher ((c) approximately 2.5 -fold changes), while CDK2 gene was downregulated (d). Importantly, cell cycle suppressor genes, p15 (e) and p21 (f), were downregulated in response to both W/DAE and HAnano ${ }^{\circledR}$. The graphs bring the $n$-fold change of the profile of transcripts normalized to the $18 \mathrm{~S}$ gene (housekeeping gene). Significant differences were considered when $\mathrm{p}<0.05$, represented by * when compared with the Ctrl group and by \# when compared to the W/DAE group.

phenotype of endothelial cells, and these data partially explain a better performance of the application of HAnano ${ }^{\circledR}$ in vivo [34], maybe by coupling angiogenesis and osteogenesis during its osseointegration processes.

\section{Data Availability}

The data that support the findings of this study are available from the corresponding author upon reasonable request.

\section{Conflicts of Interest}

The authors declare that they have no conflicts of interest.

\section{Authors' Contributions}

Pinto TS and Martins BR contributed equally in this study.

\section{Acknowledgments}

The authors are grateful to FAPESP (Fundação de Amparo à Pesquisa do Estado de São Paulo) (grant numbers: 2019/ 26854-2 and 2019/09140-6), Coordenação de Aperfeiçoa- mento de Pessoal de Nível Superior-Brasil (CAPES, code01), and CNPq for the financial support (PQ2). Also, we would like to thank Prof. Pedro Padilha for the graphite furnace atomic absorption spectrometry analysis.

\section{References}

[1] S. Tharani Kumar, S. Prasanna Devi, C. Krithika, and R. N. Raghavan, "Review of metallic biomaterials in dental applications," Journal of Pharmacy \& Bioallied Sciences, vol. 12, pp. S14-S19, 2020.

[2] B. Walkowiak, "Surface-modified metallic biomaterials in contact with blood and endothelial cells," Macromolecular Symposia, vol. 253, pp. 122-127, 2007.

[3] O. Andrukhov, C. Behm, A. Blufstein et al., "Effect of implant surface material and roughness to the susceptibility of primary gingival fibroblasts to inflammatory stimuli," Dental Materials, vol. 36, no. 6, pp. e194-e205, 2020.

[4] P. G. Coelho, J. M. Granjeiro, G. E. Romanos et al., "Basic research methods and current trends of dental implant surfaces," Journal of Biomedical Materials Research. Part B, Applied Biomaterials, vol. 88, pp. 579-596, 2009. 
[5] A. T. Sidambe, "Biocompatibility of advanced manufactured titanium implants-a review," Maternité, vol. 7, pp. 81688188, 2014.

[6] C. J. C. Fernandes, F. Bezerra, M. R. Ferreira, A. F. C. Andrade, T. S. Pinto, and W. F. Zambuzzi, "Nano hydroxyapatiteblasted titanium surface creates a biointerface able to govern Src-dependent osteoblast metabolism as prerequisite to ECM remodeling," Colloids and Surfaces. B, Biointerfaces, vol. 163, pp. 321-328, 2018.

[7] F. Bezerra, M. R. Ferreira, G. N. Fontes et al., "Nano hydroxyapatite-blasted titanium surface affects pre-osteoblast morphology by modulating critical intracellular pathways," Biotechnology and Bioengineering, vol. 114, pp. 1888-1898, 2017.

[8] R. E. Baier, A. E. Meyer, J. R. Natiella, R. R. Natiella, and J. M. Carter, "Surface properties determine bioadhesive outcomes: methods and results," Journal of Biomedical Materials Research, vol. 18, pp. 337-355, 1984.

[9] E. Pepla, L. K. Besharat, G. Palaia, G. Tenore, and G. Migliau, "Nano-hydroxyapatite and its applications in preventive, restorative and regenerative dentistry: a review of literature," Annali di Stomatologia, vol. 5, pp. 108-114, 2014.

[10] M. R. Ferreira, G. A. Santos, C. A. Biagi, W. A. Silva Junior, and W. F. Zambuzzi, "GSVA score reveals molecular signatures from transcriptomes for biomaterials comparison," Journal of Biomedial Materials Research Part A, vol. 109, pp. 10041014, 2021.

[11] M. I. P. Machado, A. M. Gomes, M. F. Rodrigues et al., "Cobalt-chromium-enriched medium ameliorates shearstressed endothelial cell performance," Journal of Trace Elements in Medicine and Biology, vol. 54, pp. 163-171, 2019.

[12] W. F. Zambuzzi, P. G. Coelho, G. G. Alves, and J. M. Granjeiro, "Intracellular signal transduction as a factor in the development of "Smart" biomaterials for bone tissue engineering," Biotechnology and Bioengineering, vol. 108, pp. 1246-1250, 2011.

[13] C. J. da Costa Fernandes, T. S. Pinto, H. R. Kang et al., "Layered double hydroxides are promising nanomaterials for tissue bioengineering application," Advanced Biosystems, vol. 3, article e1800238, 2019.

[14] S. Gemini-Piperni, E. R. Takamori, S. C. Sartoretto et al., "Cellular behavior as a dynamic field for exploring bone bioengineering: a closer look at cell-biomaterial interface," Archives of Biochemistry and Biophysics, vol. 561, pp. 88-98, 2014.

[15] B. R. Martins, T. S. Pinto, C. J. da Costa Fernandes, F. Bezerra, and W. F. Zambuzzi, "PI3K/AKT signaling drives titaniuminduced angiogenic stimulus," Journal of Materials Science. Materials in Medicine, vol. 32, 2021.

[16] S. K. Ramasamy, A. P. Kusumbe, M. Schiller et al., "Blood flow controls bone vascular function and osteogenesis," Nature Communications, vol. 7, pp. 1-13, 2016.

[17] A. P. Kusumbe, S. K. Ramasamy, and R. H. Adams, "Coupling of angiogenesis and osteogenesis by a specific vessel subtype in bone," Nature, vol. 507, pp. 323-328, 2014.

[18] C. J. da Costa Fernandes, M. R. Ferreira, F. J. B. Bezerra, and W. F. Zambuzzi, "Zirconia stimulates ECM-remodeling as a prerequisite to pre-osteoblast adhesion/proliferation by possible interference with cellular anchorage," Journal of Materials Science. Materials in Medicine, vol. 29, p. 41, 2018.

[19] N. G. dela Paz, T. E. Walshe, L. L. Leach, M. Saint-Geniez, and P. A. D'Amore, "Role of shear-stress-induced VEGF expres- sion in endothelial cell survival," Journal of Cell Science, vol. 125, pp. 831-843, 2012.

[20] T. S. Pinto, C. J. . C. Fernandes, R. A. da Silva et al., "c-Src kinase contributes on endothelial cells mechanotransduction in a heat shock protein 70-dependent turnover manner," Journal of Cellular Physiology, vol. 234, no. 7, pp. 11287-11303, 2019.

[21] M. Gottlander, C. B. Johansson, A. Wennerberg, T. Albrektsson, S. Radin, and P. Ducheyne, "Bone tissue reactions to an electrophoretically applied calcium phosphate coating," Biomaterials, vol. 18, pp. 551-557, 1997.

[22] L. Meirelles, A. Arvidsson, M. Andersson, P. Kjellin, T. Albrektsson, and A. Wennerberg, "Nano hydroxyapatite structures influence early bone formation," Journal of Biomedical Materials Research. Part A, vol. 87, pp. 299-307, 2008.

[23] R. A. da Silva, M. R. Ferreira, A. M. Gomes, and W. F. Zambuzzi, "Lnc RNA HOTAIR is a novel endothelial mechanosensitive gene," Journal of Cellular Physiology, vol. 235, pp. 46314642, 2020.

[24] C. J. da Costa Fernandes, G. S. de Almeida, T. S. Pinto, S. A. Teixeira, F. J. Bezerra, and W. F. Zambuzzi, "Metabolic effects of CoCr-enriched medium on shear-stressed endothelial cell and osteoblasts: a possible mechanism involving a hypoxic condition on bone healing," Materials Science \& Engineering. C, Materials for Biological Applications, vol. 128, p. 112353, 2021.

[25] R. A. da Silva, A. F. de Camargo Andrade, G. da Silva Feltran et al., "The role of triiodothyronine hormone and mechanically-stressed endothelial cell paracrine signalling synergism in gene reprogramming during hBMSCstimulated osteogenic phenotype in vitro," Molecular and Cellular Endocrinology, vol. 478, pp. 151-167, 2018.

[26] K.-S. Heo, K. Fujiwara, and J. Abe, "Shear stress and atherosclerosis," Molecules and Cells, vol. 37, pp. 435-440, 2014.

[27] R. A. da Silva, C. J. D. C. Fernandes, G. D. S. Feltran et al., "Laminar shear stress-provoked cytoskeletal changes are mediated by epigenetic reprogramming of TIMP1 in human primary smooth muscle cells," Journal of Cellular Physiology, vol. 234, no. 5, pp. 6382-6396, 2019.

[28] A. M. Gomes, T. S. Pinto, C. J. da Costa Fernandes, R. A. da Silva, and W. F. Zambuzzi, "Wortmannin targeting phosphatidylinositol 3-kinase suppresses angiogenic factors in shear-stressed endothelial cells," Journal of Cellular Physiology, vol. 235, no. 6, pp. 5256-5269, 2020.

[29] C. J. da Costa Fernandes, F. J. B. Bezerra, B. de Campos Souza, M. A. Campos, and W. F. Zambuzzi, "Titanium-enriched medium drives low profile of ECM remodeling as a prerequisite to pre-osteoblast viability and proliferative phenotype," Journal of Trace Elements in Medicine and Biology, vol. 50, pp. 339-346, 2018.

[30] C. J. C. Fernandes, F. Bezerra, M. . D. do Carmo et al., "CoCrenriched medium modulates integrin-based downstream signaling and requires a set of inflammatory genes reprograming in vitro," Journal of Biomedical Materials Research. Part A, vol. 106, no. 3, pp. 839-849, 2018.

[31] F. A. Silva, C. C. F. Padilha, L. E. Pezzato, M. M. Barros, and P. M. Padilha, "Determination of chromium by GFAAS in slurries of fish feces to estimate the apparent digestibility of nutrients in feed used in pisciculture," Talanta, vol. 69, pp. 1025-1030, 2006.

[32] W. F. Zambuzzi, E. A. Bonfante, R. Jimbo et al., "Nanometer scale titanium surface texturing are detected by signaling 
pathways involving transient FAK and Src activations," PLoS One, vol. 9, article e95662, 2014.

[33] R. A. da Silva, G. da Silva Feltran, M. R. Ferreira, P. F. Wood, F. Bezerra, and W. F. Zambuzzi, "The impact of bioactive surfaces in the early stages of osseointegration: an $<$ i $>$ In Vitro $<$ / i> comparative study evaluating the HAnano ${ }^{\circledR}$ and SLActive ${ }^{\circledR}$ super hydrophilic surfaces," BioMed Research International, vol. 2020, Article ID 3026893, 11 pages, 2020.

[34] S. C. Sartoretto, J. Calasans-Maia, R. Resende et al., "The influence of nanostructured hydroxyapatite surface in the early stages of osseointegration: a multiparameter animal study in low-density bone," International Journal of Nanomedicine, vol. 15, pp. 8803-8817, 2020.

[35] J. Street, M. Bao, L. de Guzman et al., "Vascular endothelial growth factor stimulates bone repair by promoting angiogenesis and bone turnover," Proceedings of the National Academy of Sciences of the United States of America, vol. 99, pp. 96569661, 2002.

[36] H. Eckardt, M. Ding, M. Lind, E. S. Hansen, K. S. Christensen, and I. Hvid, "Recombinant human vascular endothelial growth factor enhances bone healing in an experimental nonunion model," Journal of Bone and Joint Surgery. British Volume (London), vol. 87, pp. 1434-1438, 2005.

[37] T. Tarkka, A. Sipola, T. Jämsä et al., “Adenoviral VEGF-A gene transfer induces angiogenesis and promotes bone formation in healing osseous tissues," The Journal of Gene Medicine, vol. 5, pp. 560-566, 2003.

[38] C. Maes, S. Goossens, S. Bartunkova et al., "Increased skeletal VEGF enhances beta-catenin activity and results in excessively ossified bones," The EMBO Journal, vol. 29, pp. 424-441, 2010.

[39] W. Yang, D. Guo, M. A. Harris et al., "Bmp 2 in osteoblasts of periosteum and trabecular bone links bone formation to vascularization and mesenchymal stem cells," Journal of Cell Science, vol. 126, pp. 4085-4098, 2013.

[40] C. Colnot, Z. Thompson, T. Miclau, Z. Werb, and J. A. Helms, "Altered fracture repair in the absence of MMP9," Development, vol. 130, pp. 4123-4133, 2003.

[41] C. S. Albano, A. Moreira Gomes, G. da Silva Feltran et al., "Biofunctionalization of titanium surfaces with alendronate and albumin modulates osteoblast performance," Heliyon, vol. 6, pp. e04455-e04455, 2020.

[42] T. Accorsi-Mendonça, K. B. D. S. Paiva, W. F. Zambuzzi et al., "Expression of matrix metalloproteinases-2 and -9 and RECK during alveolar bone regeneration in rat," Journal of Molecular Histology, vol. 39, pp. 201-208, 2008.

[43] W. F. Zambuzzi, C. L. Yano, A. D. M. Cavagis, M. P. Peppelenbosch, J. M. Granjeiro, and C. V. Ferreira, "Ascorbate-induced osteoblast differentiation recruits distinct MMP-inhibitors: RECK and TIMP-2," Molecular and Cellular Biochemistry, vol. 322, pp. 143-150, 2009.

[44] A. C. C. de Oliveira Demarchi, W. F. Zambuzzi, K. B. S. Paiva et al., "Development of secondary palate requires strict regulation of ECM remodeling: sequential distribution of RECK, MMP-2, MMP-3, and MMP-9," Cell and Tissue Research, vol. 340, no. 1, pp. 61-69, 2010.

[45] C. J. C. Fernandes, M. R. Veiga, M. T. S. Peracoli, and W. F. Zambuzzi, "Modulatory effects of silibinin in cell behavior during osteogenic phenotype," Journal of Cellular Biochemistry, vol. 120, pp. 13413-13425, 2019.

[46] K. B. S. Paiva, W. F. Zambuzzi, T. Accorsi-Mendonça et al., "Rat forming incisor requires a rigorous ECM remodeling modulated by MMP/RECK balance," Journal of Molecular Histology, vol. 40, pp. 201-207, 2009.

[47] C. J. da Costa Fernandes and W. F. Zambuzzi, "Fibroblastsecreted trophic factors contribute with ECM remodeling stimulus and upmodulate osteocyte gene markers in osteoblasts," Biochimie, vol. 168, pp. 92-99, 2020.

[48] R. S. Carvalho, T. A. Einhorn, W. Lehmann et al., "The role of angiogenesis in a murine tibial model of distraction osteogenesis," Bone, vol. 34, pp. 849-861, 2004.

[49] A. D. Diwan, M. X. Wang, D. Jang, W. Zhu, and G. A. Murrell, "Nitric oxide modulates fracture healing," Journal of Bone and Mineral Research: the Official Journal of the American Society for Bone and Mineral Research, vol. 15, pp. 342-351, 2000.

[50] J. L. Jewell, Y. C. Kim, R. C. Russell et al., "Metabolism. Differential regulation of mTORC1 by leucine and glutamine," Science, vol. 347, pp. 194-198, 2015.

[51] X. Cai, C. Zhu, Y. Xu et al., "Alpha-ketoglutarate promotes skeletal muscle hypertrophy and protein synthesis through Akt/mTOR signaling pathways," Scientific Reports, vol. 6, p. 26802, 2016.

[52] B. Icli, W. Wu, D. Ozdemir et al., "MicroRNA-615-5p regulates angiogenesis and tissue repair by targeting AKT/eNOS (protein kinase B/endothelial nitric oxide synthase) signaling in endothelial cells," Arteriosclerosis, Thrombosis, and Vascular Biology, vol. 39, pp. 1458-1474, 2019.

[53] S. Hazarika, A. O. Dokun, Y. Li, A. S. Popel, C. D. Kontos, and B. H. Annex, "Impaired angiogenesis after hindlimb ischemia in type 2 diabetes mellitus: differential regulation of vascular endothelial growth factor receptor 1 and soluble vascular endothelial growth factor receptor 1," Circulation Research, vol. 101, pp. 948-956, 2007.

[54] R. M. Bell and D. M. Yellon, "Bradykinin limits infarction when administered as an adjunct to reperfusion in mouse heart: the role of PI3K, Akt and eNOS," Journal of Molecular and Cellular Cardiology, vol. 35, pp. 185-193, 2003.

[55] R. Yao and G. M. Cooper, "Requirement for phosphatidylinositol-3 kinase in the prevention of apoptosis by nerve growth factor," Science, vol. 267, pp. 2003-2006, 1995.

[56] T. F. Franke, S. I. Yang, T. O. Chan et al., "The protein kinase encoded by the Akt proto-oncogene is a target of the PDGFactivated phosphatidylinositol 3-kinase," Cell, vol. 81, pp. 727-736, 1995. 